\title{
Induction of implantation by aromatase inhibitors in ovariectomized mice
}

\author{
J. T. $\mathrm{Wu}$ \\ Worcester Foundation for Experimental Biology, Shrewsbury, Massachusetts 01545, U.S.A.
}

\begin{abstract}
Summary. The ability of aromatase inhibitors to induce implantation in mice was tested in animals in which implantation was delayed by ovariectomy and progesterone treatment. Implantation was consistently induced by $7 \mathrm{mg}$ 4-hydroxyandrostene-3,17dione (4-OH-A), 7.5 mg 1,4,6-androstatriene-3,17-dione (ATD) or $15 \mathrm{mg}$ 4-acetoxyandrostene-3,17-dione, an activity comparable to that of $1 \mathrm{mg}$ testosterone. In intact mice treated with 2 or $10 \mathrm{mg} 4-\mathrm{OH}-\mathrm{A}$ or ATD/day from Day 2 of pregnancy (Day 1 = vaginal plug), the number and size of implantation sites were not affected. These results may not be necessarily due to inhibitory effects of the compounds on aromatase.
\end{abstract}

\section{Introduction}

Several steroids suppress the aromatization of androgens into oestrogens and are frequently used as aromatase inhibitors. The most active ones are 4-hydroxyandrostene-3,17-dione (4-OH-A), 4acetoxy-androstene-3,17-dione (4-Ac-A) and 1,4,6-androstatriene-3,17-dione (ATD) (Brodie, Marsh, Wu \& Brodie, 1979a; Brodie et al., 1982). These compounds are very useful for the study of oestrogen-dependent processes in reproductive physiology. While investigating the mechanism of androgen induction of implantation in mice reported by others (Humphrey, 1967; Roy, SenGupta \& Manchanda, 1980), we observed a synergistic activity of aromatase inhibitors and testosterone. We therefore determined (1) the ability of aromatase inhibitors to induce implantation in ovariectomized pregnant mice, and (2) whether these compounds can inhibit or interfere with implantation in intact pregnant mice.

\section{Materials and Methods}

Treatment of ovariectomized mice. Mature CD-1 mice purchased from Charles River Breeding Laboratories were maintained in air-conditioned quarters with lights on from $06: 00$ to $20: 00 \mathrm{~h}$. The females were caged with males and examined every morning for the presence of a vaginal plug which was considered as a sign of mating (Day 1 of pregnancy). On the afternoon of Day 3, the females were anaesthetized with pentobarbitone sodium and the ovaries were carefully removed, leaving the oviducts as little disturbed as possible. From then on, the females received a daily s.c. injection of $1 \mathrm{mg}$ progesterone in corn oil until killed. The ovariectomy combined with the progesterone treatment causes a delay in implantation. On Day 8 or 9 , the females were injected s.c. with various doses of aromatase inhibitors (4-OH-A, 4-Ac-A or ATD, see Table 1). They were killed 3 days later and the uteri were examined for implantation sites. Based on our experience, animals with implantation sites larger than $3.5 \mathrm{~mm}$ were considered to have implanted before treatment and thus excluded from the data. If no implantation sites were present, the uteri were flushed with $0.9 \%$ (w/v) $\mathrm{NaCl}$ and the flushings were examined for blastocysts under a dissecting microscope $(\times 32)$. Animals without implantation sites or blastocysts were also excluded.

Aromatase inhibitors were finely ground and suspended in an aqueous steroid-suspending vehicle obtained from National Cancer Institute, NIH, Bethesda, MD : $1 \mathrm{ml}$ of the vehicle contains 
$9 \mathrm{mg}$ sodium chloride, $5 \mathrm{mg}$ sodium carboxymethylcellulose-7; $4 \mu \mathrm{l}$ polysorbate $80 ; 9 \mu$ benzyl alcohol and the balance water. Each dose was split into 3 equal subdoses given in $0.05 \mathrm{ml}$ vehicle $3-$ $4 \mathrm{~h}$ apart. For comparison, testosterone was also studied.

Treatment of intact mice. To investigate whether aromatase inhibitors can inhibit or interfere with normal implantation in intact mice, pregnant animals were allocated to the following treatment groups: (1) vehicle only controls; (2) 4-OH-A, $2 \mathrm{mg} /$ day; (3) 4-OH-A, $10 \mathrm{mg} / \mathrm{day}$; (4) ATD, $2 \mathrm{mg} /$ day; and (5) ATD, $10 \mathrm{mg} /$ day. The daily dose was given s.c. in 4 equal split-doses in 50 $\mu \mathrm{l}$ vehicle at 07:00, 12:00, 17:00 and 23:00 h ( $\pm 30 \mathrm{~min})$ from Day 2 until autopsy. The animals were killed at 20:30 h on Day 5 or 10:00 h on Day 6 or Day 7, 10 min after an i.v. injection of 0.1 $\mathrm{ml} 0.9 \%(\mathrm{w} / \mathrm{v}) \mathrm{NaCl}$ containing $1 \%$ Niagara Sky Blue to help identify early implantation sites (Psychoyos, 1967). The size, number and location of implantation sites were recorded.

\section{Results}

\section{Induction of implantation in ovariectomized pregnant mice}

The results are presented in Table 1. Of the three aromatase inhibitors studied, 4-Ac-A was the least active in inducing implantation in ovariectomized mice. It required $15 \mathrm{mg} \mathrm{4-Ac-A}$ to cause $100 \%$ implantation in the treated mice, while comparable results were obtained with $7 \mathrm{mg} 4-\mathrm{OH}-\mathrm{A}$ and $7.5 \mathrm{mg} \mathrm{ATD}$. At the latter dose, 4-Ac-A caused implantation in only 1 out of 10 treated mice. At a dose of $3.2 \mathrm{mg}$, ATD caused 5 of $13(40 \%)$ mice to implant while an equimolar amount of 4-OH-A $(3.5 \mathrm{mg})$, resulted in no implantations (not statistically significant by $\chi^{2}$ test).

Table 1. Induction of implantation in ovariectomized mice by aromatase inhibitors and testosterone

\begin{tabular}{|c|c|c|c|c|}
\hline \multirow[b]{2}{*}{ Compound } & \multirow[b]{2}{*}{$\begin{array}{c}\text { Dose } \\
\mathrm{mg}(\mu \mathrm{mol})\end{array}$} & \multicolumn{3}{|c|}{ No. of mice } \\
\hline & & Treated & $\begin{array}{l}\text { With implantation sites } \\
\text { (mean } \pm \text { s.e.m. sites) }\end{array}$ & $\begin{array}{c}\text { With blastocysts } \\
\text { (mean } \pm \text { s.e.m. blastocysts) }\end{array}$ \\
\hline Vehicle & $0.15 \mathrm{ml}$ & 16 & 0 & $16(7 \cdot 3 \pm 0 \cdot 9)$ \\
\hline \multirow[t]{2}{*}{ 4-OH-A } & $3.5(12)$ & 4 & 0 & $4(3.0 \pm 0.9)$ \\
\hline & $7 \cdot 0(23)$ & 12 & $11(8.4 \pm 0.9)$ & $1(2)$ \\
\hline \multirow[t]{3}{*}{ ATD } & $1.6(5 \cdot 8)$ & 9 & 0 & $9(5.4 \pm 1.0)$ \\
\hline & $3 \cdot 2(12)$ & 13 & $5 \quad(7 \cdot 8 \pm 1 \cdot 5)$ & $8(6.1 \pm 0.7)$ \\
\hline & $7 \cdot 5(27)$ & 12 & $12(11.6 \pm 1.0)$ & 0 \\
\hline \multirow[t]{3}{*}{ 4-Ac-A } & $7 \cdot 5(23)$ & 10 & $1(12)$ & $9(3.3 \pm 0.5)$ \\
\hline & $11 \cdot 0(34)$ & 5 & $3(10 \cdot 0 \pm 1 \cdot 5)$ & $2(4 \cdot 0 \pm 1 \cdot 0)$ \\
\hline & $15 \cdot 0(46)$ & 5 & $5(8.0 \pm 1.6)$ & 0 \\
\hline \multirow[t]{3}{*}{ Testosterone } & $0.5(1.7)$ & 11 & $5 \quad(6.2 \pm 1.7)$ & $6(5 \cdot 2 \pm 0 \cdot 8)$ \\
\hline & $1.0(3.5)$ & 9 & $8(6.4 \pm 1.3)$ & $1(7)$ \\
\hline & $2 \cdot 0(7)$ & 4 & $4(10 \cdot 0 \pm 3 \cdot 1)$ & 0 \\
\hline
\end{tabular}

In comparison with the aromatase inhibitors, testosterone was much more active in inducing implantation (Table 1).

\section{Effects on implantation in intact pregnant animals}

Treatment of pregnant mice with $4-\mathrm{OH}-\mathrm{A}$ or ATD at 2 or $10 \mathrm{mg} /$ day had no effects on the number (Table 2) or size of implantation sites as compared with the controls. However, in mice treated with 4-OH-A (Groups 2 and 3), implantation sites were generally crowded to the upper portion of each horn (Text-fig. 1). This was also true if the treatment was started on Day 3 of 
Table 2. Implantation in mated mice treated with 4-OH-A and ATD

\begin{tabular}{clcc}
\hline Group & \multicolumn{1}{c}{ Treatment } & $\begin{array}{c}\text { No. of mice } \\
\text { treated }\end{array}$ & $\begin{array}{c}\text { No. of } \\
\text { implantation sites } \\
\text { (mean } \pm \text { s.e.m.) }\end{array}$ \\
\hline 1 & $0 \cdot 2 \mathrm{ml}$ vehicle/day & 5 & $11 \cdot 2 \pm 1 \cdot 0$ \\
2 & $2 \mathrm{mg} \mathrm{4-OH-A/day}$ & 5 & $10 \cdot 0 \pm 1 \cdot 4$ \\
3 & $10 \mathrm{mg} \mathrm{4-OH-A/day}$ & 5 & $9 \cdot 4 \pm 0 \cdot 7$ \\
4 & $2 \mathrm{mg} \mathrm{ATD} /$ day & 4 & $11 \cdot 8 \pm 2 \cdot 0$ \\
5 & $10 \mathrm{mg} \mathrm{ATD}$ /day & 4 & $9 \cdot 8 \pm 2.8$ \\
\hline
\end{tabular}

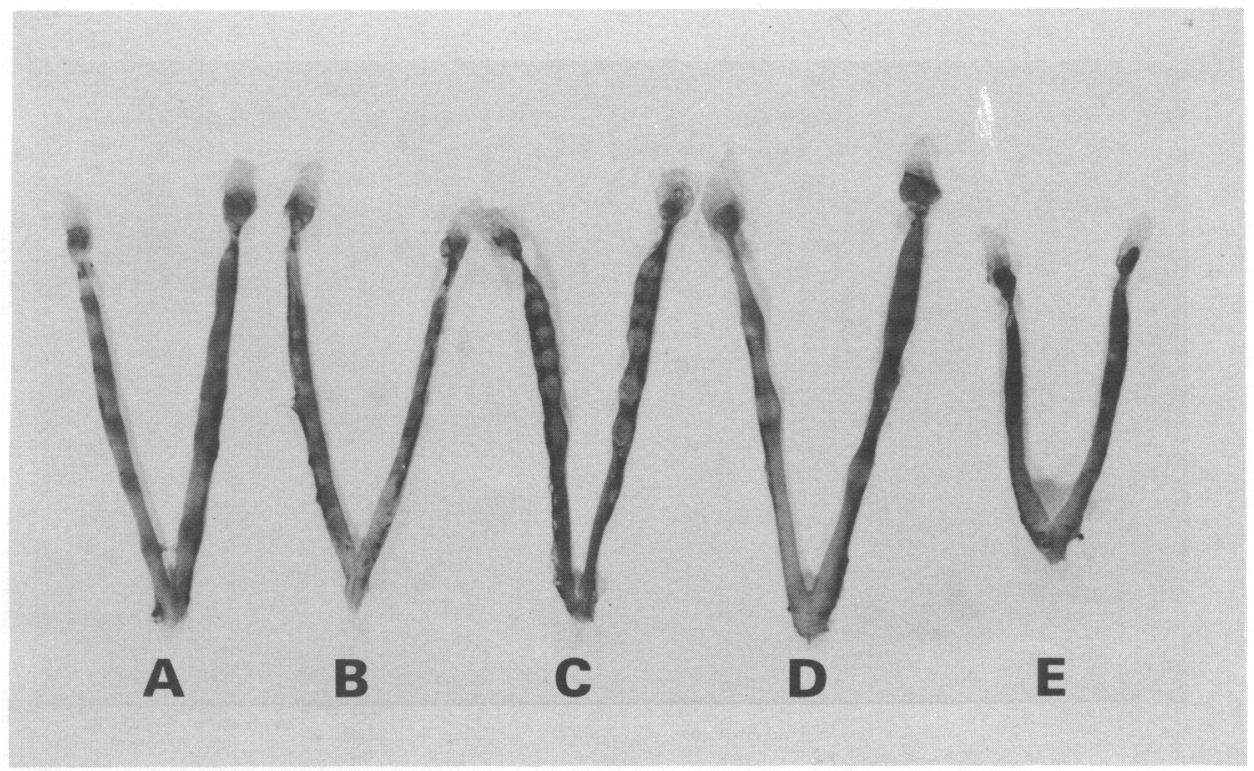

Text-fig. 1. Spacing of implantation sites in mice treated with aromatase inhibitors, ATD and 4-OH-A. Implantation sites were more or less evenly spaced in ATD-treated mice (A and B, both Day 6 of pregnancy), but were crowded in the upper part of each horn in 4-OH-A-treated mice (C and D, both Day 7, and E, Day 5 evening). A, B and E are from mice receiving Niagara Sky Blue before being killed. All uteri had been fixed in Mossman's acetic acid-formalinalcohol fixative overnight before photography. The number of implantation sites in the left and right horn of each animal is as follows: A, 6, 5; B, 7, 6; C, 6, 6; D, 2, 7; and E, 6, 5 .

pregnancy (data not shown). In mice treated with vehicle alone (Group 1) or with ATD (Groups 4 and 5), the implantation sites were more or less evenly distributed along the entire horn.

\section{Discussion}

In rats, the aromatase inhibitors, ATD, 4-Ac-A and 4-OH-A, not only compete with androstenedione and testosterone for aromatase, but also cause irreversible inactivation of the enzyme, probably through some enzyme-generated intermediates (Covey \& Hood, 1981; Brodie et al., 1981b). These compounds, in a single injection at $50 \mathrm{mg} / \mathrm{kg}$ or $10-12 \mathrm{mg} / \mathrm{rat}$, can drastically reduce oestrogen secretion from the ovary by $80 \%$ and, in multiple injections at $50 \mathrm{mg} / \mathrm{kg} / \mathrm{day}$, prevent or delay implantation of the embryo in many rats, with 4-OH-A being the most effective 
(Brodie, Schwarzel, Shaikh \& Brodie, 1977; Brodie, Wu, Marsh \& Brodie, 1978, 1979b). On the other hand, implantation in hamsters does not require oestrogen and is not significantly affected by 4-Ac-A (Brodie et al., 1978).

The present study has shown that these aromatase inhibitors are capable of inducing implantation in mated mice that were ovariectomized and maintained on progesterone, although they are only weakly active as it requires seven times as much 4-OH-A (7 mg) and ATD (7.5 mg) and 15 times as much $4-\mathrm{Ac}-\mathrm{A}(15 \mathrm{mg})$ as testosterone $(1 \mathrm{mg})$ to cause implantation. Androgens such as testosterone propionate (Humphrey, 1967) and $5 \alpha$-dihydrotestosterone induce implantation in ovariectomized mice (Roy et al., 1980) and rats (Varavudhi, 1969). It has been suggested that $5 \alpha-$ dihydrotestosterone acts only through oestrogen receptors, while testosterone acts through testosterone and oestrogen receptors in the mouse uterus (Roy et al., 1980). However, the possibility of testosterone being converted to oestrogen by extra-ovarian and adrenal sites cannot be excluded (Varavudhi, 1969). Although the mechanism by which the aromatase inhibitors bring about implantation in ovariectomized mice is not clear, it is possible that the compounds, as modified androgens, could cause implantation through mechanisms similar to those of testosterone, in addition to through their metabolites such as 4-hydroxytestosterone and 4-hydroxyoestrone (Brodie, Romanoff \& Williams, 1981a; Marsh, Romanoff, Williams, Brodie \& Brodie, 1982).

The failure of 4-OH-A and ATD treatment to interfere with implantation in intact mated mice is contrary to the results reported for rats (Brodie et al., 1977, 1978, 1979b). This is unexpected because in rats and mice oestrogen and progesterone are required for implantation. The observation that $4-\mathrm{OH}-\mathrm{A}$ at 2 and $10 \mathrm{mg} /$ day caused uneven spacing of implantation sites suggests that oestrogen secretion was reduced, causing a decrease in the motility of the uterine horn. Although ATD and 4-OH-A had comparable activities in inducing implantation in ovariectomized mice, ATD treatment did not interfere with embryo spacing in the uterus, suggesting that ATD may be less effective than 4-OH-A in inhibiting oestrogen secretion in mice. However, in spite of the presumed decreased level of oestrogen secretion, it was still sufficient for the aromatase inhibitors to cause implantation, regardless of the dosage.

Because of the ability of these aromatase inhibitors to induce implantation in ovariectomized mice, the experimental results obtained with these compounds, especially when administered into the uterus (e.g. Wu \& Lin, 1982), may not be necessarily due to their inhibitory effect on aromatase.

This study was supported by NIH Grant HD-12047. We thank Dr Angela M. H. Brodie and Dr Harry J. Brodie for the aromatase inhibitors.

\section{References}

Brodie, A.M.H., Schwarzel, W.C., Shaikh, A.A. \& Brodie, H.J. (1977) The effect of an aromatase inhibitor, 4hydroxy-4-androstene-3,17-dione on estrogen-dependent processes in reproduction and breast cancer. Endocrinology 100, 1684-1696.

Brodie, A.M.H., Wu, J.T., Marsh, D.A. \& Brodie, H.J. (1978) Aromatase inhibitors. III. Studies on the antifertility effect of 4-acetoxy-4-androstene-3,17dione. Biol. Reprod. 18, 365-370.

Brodie, A.M.H., Marsh, D.A., Wu, J.T. \& Brodie, H.J. (1979a) Aromatase inhibitors and their use in controlling oestrogen-dependent processes. J. Steroid Biochem. 11, 107-112.

Brodie, A.M.H., Wu, J.T., Marsh, D.A. \& Brodie, H.J. (1979b) Antifertility effects of an aromatase inhibitor, 1,4,6-androstatriene-3,17-dione. Endocrinology 104, $118-121$.
Brodie, A.M.H., Romanoff, L.P. \& Williams, K.I.H. (1981a) Metabolism of the aromatase inhibitor 4hydroxy-4-androstene-3,17-dione by male rhesus monkeys. J. Steroid Biochem. 14, 693-696.

Brodie, A.M.H., Garrett, W.M., Hendrickson, J.R., TsiaMorris, C.H., Marcotte, P.A. \& Robinson, C.H. (1981b) Inactivation of aromatase in vitro by 4hydroxy-androstene-3,17-dione and 4-acetoxy-4-androstene-3,17-dione and sustained effects in vivo. Steroids 38, 693-702.

Brodie, A.M.H., Brodie, H.J., Romanoff, L., Williams, J.G., Williams, K.I.H. \& Wu, J.T. (1982) Inhibition of estrogen biosynthesis and regression of mammary tumours by aromatase inhibitors. In Hormones and Cancer, pp. 179-190. Ed. W. W. Leavitt. Plenum Publishing, New York. 
Covey, D.F. \& Hood, W.F. (1981) Enzyme-generated intermediates derived from 4-androstene-3,6,17trione and 1,4,6-androstatriene-3,17-dione cause a time-dependent decrease in human placental aromatase activity. Endocrinology 108, 1597-1599.

Humphrey, W.K. (1967) The induction of implantation in the mouse after ovariectomy. Steroids 10,591-600.

Marsh, D.A., Romanoff, L., Williams, K.I.H., Brodie, H.J. \& Brodie, A.M.H. (1982) Synthesis of deuterium- and tritium-labeled 4-hydroxyandrostene-3,17dione, an aromatase inhibitor, and its metabolism in vitro and in vivo in the rat. Biochem. Pharmacol. 31, $701-705$.
Psychoyos, A. (1967) The hormonal interplay controlling egg-implantation in the rat. Adv. Reprod. Physiol. 2, 257-277.

Roy, S.K., SenGupta, J. \& Manchanda, S.K. (1980) Induction of implantation by androgens in mice with delayed implantation. $J$. Reprod. Fert. 58, 339-343.

Varavudhi, P. (1969) Stimulation of blastocyst implantation in long-term hypophysectomized and ovariectomized pregnant rats by means of androgens. Biol. Reprod. 1, 247-252.

Wu, J.T. \& Lin, G.M. (1982) Effect of aromatase inhibitor on oestrogen production in rabbit blastocysts. J. Reprod. Fert. 66, 655 662.

Received 16 January 1984 